\title{
Strategies on the development of ecotourism at the Bucharest in the context of globalization
}

\author{
Cristina Alpopi ${ }^{1, *}$, Silviu Diaconu ${ }^{2}$, and Elena Rusalca Velicu $^{2}$ \\ ${ }^{1}$ Bucharest University of Academic Studies, Romania \\ ${ }^{2}$ Bucharest University of Academic Studies, Romania
}

\begin{abstract}
Tourism is the activity practiced by people who want new experiences, free to visit places much dreamed of in order to improve their inner state through everything that is beautiful, both visually and thanks to the accumulated interests that simultaneously lead to the enrichment of general knowledge and not no more. Tourism has become an important area that has succeeded in establishing itself in Romania, having positive effects on the economy, increasing labor force, capitalizing on the tourism potential, demand and tourism supply are constantly increasing, all of which implicitly improve living conditions. Bucharest, the main political, economic and administrative center of Romania, has become one of the most important national tourist destinations over the years, but much is due exclusively to business tourism, and leisure tourism is somewhat smaller. This article brings to the fore the ecotourism principles developed at the level of the capital of Romania, in the context of a globe that is subject to globalization and its socio-economic impact. There will be identified the main strategic directions for creating a well-developed ecotourism standard for economic progress and attracting a large flow of tourists in this earlystage form of development. This article brings to the fore the principles of ecotourism developed at the level of the capital of Romania, in the international context of globalization and its socio-economic impact. The main strategic directions for creating a well-developed ecotourism standard for economic progress and attracting a flow of tourists into this form of early development will be identified.
\end{abstract}

\section{Introduction}

Tourism has become an important area that has succeeded in establishing itself in Romania, having positive effects on the economy, increasing labor force, capitalizing on the tourism potential, demand and tourism supply are constantly increasing, all of which implicitly improve living conditions [1]. Bucharest, the main political, economic and administrative center of Romania, has become one of the most important national tourist destinations over the years, but much is due exclusively to business tourism, and loisir tourism is somewhat smaller [2].

In addition to the usual tourism, the concept of ecotourism has not been heard in Bucharest, this phenomenon is not discussed or even capitalized, of course, being usually

* Corresponding author: calpopi07@yahoo.com 
carried out outside the cities [3]. However, it seems that it is possible in the capital, too, and there is already a small part of an untapped nature [4].

In this paper, we will present the general characteristics of the tourist space in Bucharest, the size of the tourism economy, the tourist potential, the offer and the touristic circulation and, last but not least, the strategies for the sustainable development of cultural tourism, as well as the ecotourism at Bucharest level.

Ecotourism is a sub-component of the field of sustainable tourism. Ecotourism's perceived potential as an effective tool for sustainable development is the main reason why developing countries are now embracing it and including it in their economic development and conservation strategies [5].

The phenomenon of globalization, which is almost at the level of all economic systems, has also influenced tourism from a complex perspective: geopolitical, economic or cultural [6]. Globalization presupposes the existence of a permanent cooperation between the national economies and their adherence to a world economic system [7].

The very concept of "national economy" has changed its meaning, the world's leading economic institution has become the transnational corporation that locates its subsidiaries and markets its products without considering the existence of state borders [8].

In the tourism sector, the phenomenon of globalization has caused many changes such as [9]: organizing the necessary logistics for transport on regional or even global structures, defining international rules of conduct, developing and specializing different forms of tourism, turning some areas into a tourist destination only after the penetration of some structures global tourism professionals in that region [10]. In the context of globalization, the prosperity of nations is measured by the level of competitiveness on international markets [11]. So the issue of competitiveness has become a topic of greatest interest to every actor of the world economy and for every economic sector [12].

\section{Methods}

Research methods are inventory-analysis of ecotourism resources in the capital of Romania. At the same time, the analysis is based on data and information taken from documentation and site visits. In order to determine durable strategies for the city, the main tourism indicators were analysed, namely the existing accommodation structures, as well as the tourist traffic during the analyzed period. Finally, a sustainable development framework for the city from the ecotourism perspective has emerged, taking into account the characteristics of globalization.

Taking into account the cultural elements and the anthropic landscaping of great importance, Bucharest is a potential patrimony of ecotourism evaluated according to the normative acts that regulate the management of tourism resources [13].

\section{Results}

\subsection{The size of the economy of tourism and the environment in Bucharest}

The Bucharest-Ilfov region is the smallest in Romania in terms of size, covering an area of $1,821 \mathrm{~km} 2$, with $11 \%$ of the total population in the country, ranked sixth in the population.

Based on the economic activities occupied in Bucharest, out of a total of 1,593,800 persons employed in $2017,12.8 \%$ work in industry, $12.8 \%$ also work in construction, $15.7 \%$ work in real estate transactions, $18,8 \%$ work in commerce, $4 \%$ in education, $5.4 \%$ work in health, and the rest $27.7 \%$ are occupied by other activities in the national economy (General Urban Plan of Bucharest 2018). Hotels and restaurants work only $2.8 \%$ of the 
capital's population, making Bucharest the number one in the country with the highest concentration of people in the tourism sector.

In the last 5 years, the tourism industry in Bucharest has entered a positive trend both in terms of tourism demand (increases in the number of tourists and number of overnight stays) and in terms of tourist offer. The upward trend was generated by the development of business tourism, which accounts for about $85 \%$ of the total arrivals in the city, followed by loisir tourism and recreation. This was due to lower tariffs compared to other European cities.

\subsection{Offer and tourist request}

In the urban area tourist accommodation structures cover a wide variety (hotels, hostels, boarding houses, tourist villas, etc.), and besides the appropriate conditions for overnight service, they also provide other functions of service- food, recreation [14].

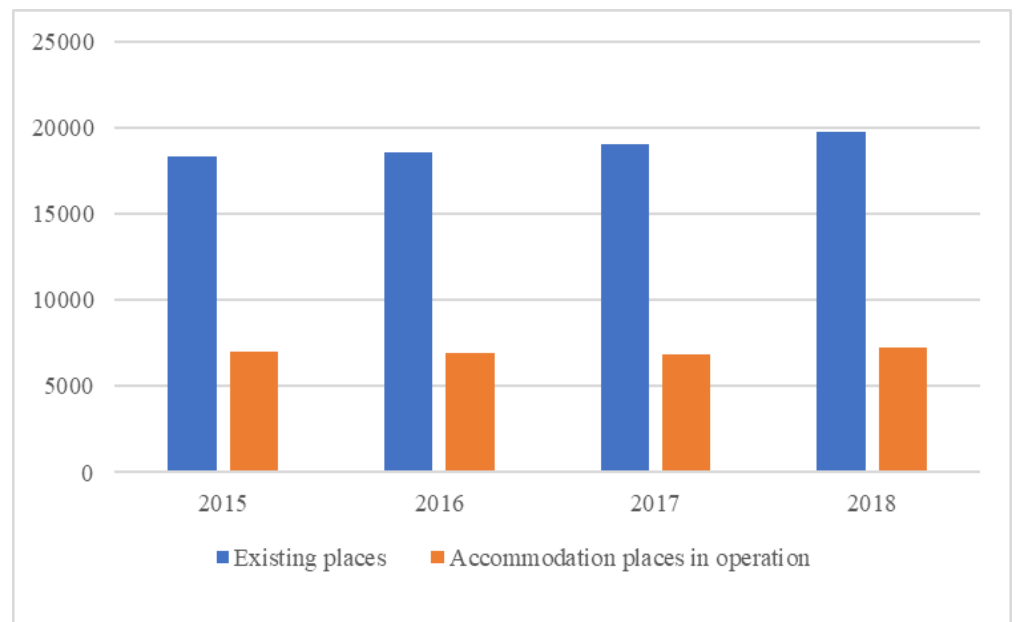

Fig. 1. The capacity and activity of tourist accommodation in Bucharest from 2015-2018 (INSSE)

In the case of existing accommodation places, there may be an increase from 2015 until 2018, reaching 19,784 thousand, and in the case of places of accommodation in service there is a decrease from 2014 until 2016, but 2018, brings the increase in accommodation places in operation reaching 7.236 thousand. By building many new structures, the majority of them fall into one category.

Tourist traffic and tourist demand are analyzed in terms of the following indicators: tourist arrivals, overnight stays and average stay [15].

In the chart (Figure 2), which represents the total number of tourists in Bucharest, it is observed that it is in continuous growth, with quite large differences in the 4 years. It is noticed that from 2015 until 2018 the number of tourists has reached 635 thousand to 1.8 million tourists. 


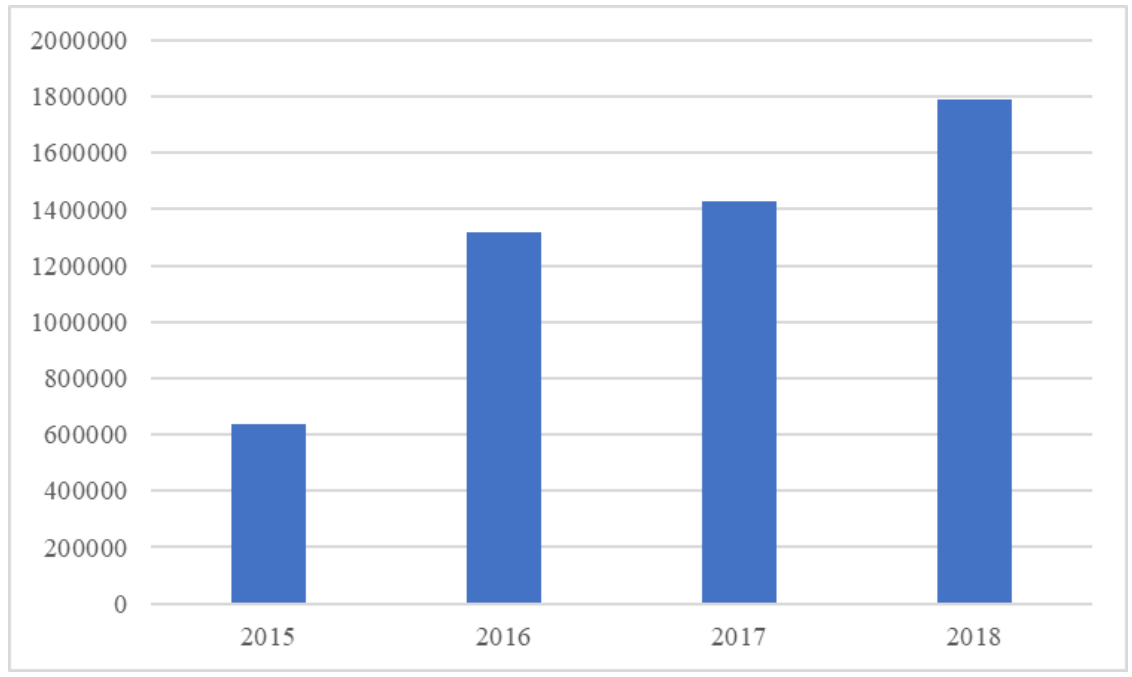

Fig. 2. Total number of tourists in Bucharest between 2015-2018 (INSSE)

\section{Discussion}

\subsection{Framework of proposed research strategies}

The first research on the dynamics of cultural sectors in Bucharest was carried out by a consortium of NGOs in early 2018. Following its consultation and following the research, three strategic themes were considered as major:

The first strategic theme is related to the poor relationship between the center of Bucharest and the periphery [16]. This refers to the relationship between the cultural offer in the Center of Bucharest and that in the peripheral and peripheral areas [17]. This is a priority theme because financial resources are mostly concentrated in the center of Bucharest, but also the small budgets of the mayoralties have led to a poor development of the cultural infrastructure. Also, the relationship between the center of Bucharest and its neighborhoods depends greatly on public transport, the center having a higher accessibility to transportation, while neighborhoods have less accessibility. Another problem is that cultural infrastructure is concentrated only in the center of the capital and neighborhoods are seen as unattractive from a cultural point of view, only the parks are the only source of attraction for neighborhoods.

The second proposed strategic theme is the recovery of urban space as a public domain for the inhabitants of Bucharest $[18,19]$. This is related to the fact that the city has become very busy and there are no special public spaces for the interaction between the citizens. It is a priority theme because Bucharest is the busiest place to be driven by traffic and pedestrians find it hard to find their place, in the last years there have been too many cars and there are also missing the necessary parking spaces [20]. Also, many districts lack the streets or bicycle and pedestrian routes to provide safe access to parks or workplaces, but especially to people with disabilities, urban accessibility remains a very important issue and is partially solved with the help of the public transport system [21].

The third proposed strategic theme is related to the saving of the Patrimony of Bucharest, because it has not been used in recent times and is a very important factor for the attractiveness of the city. Unfortunately, there is a very small number of specialists in 
the field to handle the restoration, conservation and rehabilitation of heritage. Also the Old Center, which is very visited by young and foreign tourists, lacks the architectural, historical and cultural landmarks. Linked to a list of heritage objectives that I consider representative would be the People's House or the Romanian Athenaeum and many other buildings that are seen only as cultural institutions and are not exploited enough.

As a result of the strategies proposed and defined as the most important from my point of view, several proposals were considered necessary for cultural tourism and ecotourism in Bucharest.

Table 1. Directions for the Development of Cultural Tourism and Ecotourism

\begin{tabular}{|c|c|}
\hline $\begin{array}{l}\text { Developing } \\
\text { cultural tourism at } \\
\text { Bucharest level }\end{array}$ & $\begin{array}{l}\text { - Rehabilitation and development of cultural infrastructure in } \\
\text { parks. (especially in Herastrau Park) } \\
\text { - Investments in urban furniture especially in the Old Bucharest } \\
\text { Center (light poles, garbage bins, parking lots, banks) } \\
\text { - Renovation of the facades of the buildings in the Center of } \\
\text { Bucharest, being a serious problem at present, both regarding } \\
\text { their aesthetics and the safety of the people } \\
\text { - Strengthening the infrastructure of buildings with high seismic } \\
\text { risk, which are in large numbers in the center of Bucharest due } \\
\text { to their age. } \\
\text { - Improving the quality of services provided by clubs, pubs and } \\
\text { restaurants. } \\
\text { - Creating an urban information center in the central area and } \\
\text { neighborhoods. It is preferable that information on museums, } \\
\text { maps, restaurants be provided in more than one international } \\
\text { language } \\
\text { - Building websites to promote online cultural tourism. } \\
\text { - Rehabilitation of degraded monuments and museums (for } \\
\text { example, George Enescu Museum and Antipa Museum) } \\
\text { - Improvement of road traffic, which is a major problem in } \\
\text { Bucharest and plays an important role in touring tours } \\
\text { - Improving the infrastructure needed for people with } \\
\text { disabilities }\end{array}$ \\
\hline $\begin{array}{l}\text { Developing } \\
\text { ecotourism at the } \\
\text { level of Bucharest }\end{array}$ & $\begin{array}{l}\text { - Conservation of the natural natural heritage (Văcăreşti Natural } \\
\text { Park, Dâmboviţa River, Mogoşoaia Area, Snagov Zone etc.) } \\
\text { - Stimulating the development of ecotourism in order to } \\
\text { promote the concept of sustainable development } \\
\text { - Development of ecotourism in Bucharest by promoting natural } \\
\text { objectives (example: Văcăreşti Natural Park) } \\
\text { - Creation of organized tourist routes including visiting the } \\
\text { natural areas on the outskirts of Bucharest. } \\
\text { - Because of the location of the natural areas on the outskirts of } \\
\text { Bucharest, it is necessary to improve the appearance by cleaning } \\
\text { the waste areas } \\
\text { - Cessation of the construction of dwellings or buildings used } \\
\text { for other purposes near natural protected areas would be a } \\
\text { necessity, as this will lead to environmental degradation over } \\
\text { time. }\end{array}$ \\
\hline
\end{tabular}




\section{Conclusion}

In conclusion, Bucharest City can be considered as a city with enormous potential in terms of tourism. The variety of tourist offer in Bucharest makes urban space a wide range of travel incentives, from cultural tourism, to business tourism, weekend tourism, leisure tourism, shopping tourism, and other forms of tourism such as ecotourism, which is concerned with the protection and preservation of the environment, as it is not exploited enough at the level of Bucharest, but in the future the promotion of sustainable tourism in the capital should be started by stimulating the development of ecotourism, by preserving the urban natural patrimony.

With a workforce of only $2.8 \%$ in the field of tourism, Bucharest does not leave so easily and has come to be named as the largest urban historical center and the most visited city in Romania in 2015, but also by the values impressive capital that the capital has, it also faces some important issues, such as insufficient capitalization of cultural objectives and lack of promotion at international level. For the development of sustainable urban tourism in Bucharest it is necessary first of all that the inhabitants be informed that they are the main factor that usually stops this process, that the preservation and preservation of the natural heritage is important, that the resources should not be exploited until exhaustion and that every mistake leads to the destruction of the city in the future.

As a result of the quantitative research of the tourist offer, it was observed that at the level of Bucharest approximately $84 \%$ of the tourist accommodation establishments with functions of tourist accommodation have a high degree of comfort which attracts even more tourists. Just because of the business tourism, much used in Bucharest, the majority of overnight tourists have only an average of 1.75 days per stay, which is not a good thing for the tourism economy.

Also, research has found that the most important place in Bucharest, preferred by most people, is the Historic Center of Bucharest, being the area preferred by most foreign tourists due primarily to nightlife, followed by parks and museums. However, in this area, there is a need for a plan to improve the infrastructure of buildings seriously affected by their age. We have also identified that the promotion of tourism in Bucharest is underdeveloped and that advertising should be considerably improved both in the online environment and with the help of the press. Finally, it is said that tourism in Bucharest is a real challenge for which it is still working and for which there are hopes that in the near future it will be called a European Cultural Capital.

In the context of the phenomenon of globalization, Romania needs to make many changes to become competitive in the field of tourism. Although Romania's tourism potential has been and is being praised as promising both by Romanian and foreign researchers, Romanian tourism is still in the development and rehabilitation phase. On its way to performance, Romanian tourism must adopt a global mentality and take into account the existing international competition.

\section{References}

1. M. Mazilu, C. Rabonțu, R. Marinescu, New Products and Strategies for Sustainable Tourism in Romania, Journal of Tourism \& Hospitality (2017)

2. D. M. Tudorache, Strategii de dezvoltare a turismului în municipiul București (2010)

3. C. V. Rădulescu, D. A. Bodislav, S. Burlacu, Demographic Explosion And It Governance In Public Institutions. Managerial Challenges of the Contemporary Society. Proceedings, 11, 18 (2018) 
4. F. A. Alexe, Branding de oraș. Studiu de caz: București, (Mica Valahie, Bucharest, 2017)

5. D. Zacarias, R. Loyola, How Ecotourism Affects Human Communities, Ecotourism's Promise and Peril, 133-151 (2017)

6. S. Burlacu, C. Gutu, F. O. Matei, Globalization-pros and cons. Calitatea, 19, 122-125 (2018)

7. D. Rodrik, Populism and the economics of globalization, Journal of International Business Policy, 1, 12-33 (2018)

8. L. Ruhanen, The prominence of eco in ecotourism experiences: An analysis of postpurchase online reviews, Journal of Hospitality and Tourism Management, 39, 110116 (2019)

9. U. Jamrozy, K. Lawonk, The multiple dimensions of consumption values in ecotourism, International Journal of Culture, Tourism and Hospitality Research (2017)

10. E. Mondino, Ecotourism as a learning tool for sustainable development. The case of Monviso Transboundary Biosphere Reserve (Italy, Taylor\&Francis Online, 2018)

11. S. Burlacu, D. A. Bodislav, C. V. Rădulescu, E-Commerce and Global Food Resources. Managerial Challenges of the Contemporary Society, 11, 48 (2018)

12. C. B. Onete, S. Budz, D. Starosta, B. Georgescu, Importance of sustainable ecotourism in Europe as perceived by web searches, Quality - Access to Success, Supplement 2, 20, 433-439 (2019)

13. M. Stone, P. Gyan, Ecotourism influence on community needs and the functions of protected areas: a systems thinking approach, Journal of Ecotourism, 16 (2017)

14. H. R. O'Rourke, Economic History and Contemporary Challenges to Globalization, The Journal of Economic History (2019)

15. K. Benedek, Aspects in Romanian nature conservation - a review, Environmental Engineering \& Management Journal (EEMJ), 17, 95-106 (2018)

16. I. Jianu, I. Dobre, D. A. Bodislav, C. V. Radulescu, S. Burlacu, The implications of institutional specificities on the income inequalities drivers in European Union. Economic Computation and Economic Cybernetics Studies and Research, 53, 59-76 (2019)

17. F. Bran, C. Alpopi, S. Burlacu, Territorial Development-Disparities between the Developed and the least Developed Areas of Romania. LUMEN Proceedings, 6, 146155 (2018)

18. F. Ioniţă, S. Burlacu, A. Gaidargi, Modern approaches of the management of alternative trade systems. Revista de Management Comparat Internațional/Review of International Comparative Management, 51, 473-480 (2009a)

19. F. Ionita, M. Ursacescu, S. Burlacu, Public services as poles of regional competitiveness in sustainable development. Revista de Management Comparat International/Review of International Comparative Management, 10, 552-565 (2009b)

20. F. Bran, S. Burlacu, C. Alpopi, Urban Transport of Passengers in Large Urban Agglomerations and Sustainable Development. Experience of Bucharest Municipality in Romania. European Journal of Sustainable Development, 7, 265-273 (2018)

21. S. Burlacu, Ways to Streamline the Internal and External Communication in the RATB. Economics, Management, and Financial Markets, 13, 234-240 (2018) 